\title{
Development of Teachers' Mathematical Knowledge for Teaching by Using the Innovation of Lesson Study and Open Approach
}

\author{
Anake Sudejamnong1 ${ }^{1}$ Kittipot Robsouk ${ }^{1}$, Suladda Loipha ${ }^{2}$, Maitree Inprasitha ${ }^{3}$ \\ ${ }^{1}$ Department of Doctoral Program in Mathematics Education, Khon Kaen University, Khon Kaen, Thailand \\ ${ }^{2}$ Centre for Excellent in Mathematics, $\mathrm{CHE}$, Bangkok, Thailand \\ ${ }^{3}$ Center for Research in Mathematics Education, Khon Kaen University, Khon Kaen, Thailand \\ Email: anake@sru.ac.th
}

Received 22 August 2014; revised 23 September 2014; accepted 4 October 2014

Copyright (C) 2014 by authors and Scientific Research Publishing Inc.

This work is licensed under the Creative Commons Attribution International License (CC BY). http://creativecommons.org/licenses/by/4.0/

(c) (i)

Open Access

\section{Abstract}

This research was under context of professional development for mathematics teacher by using the innovation of lesson study and open approach project implemented by the Center for Research in Mathematics Education, Faculty of Education, Khon Kaen University, during 2009-2011 academic years. The objective of this research was to study the development of mathematical knowledge for teaching of teacher from working based on 3 steps of the lesson study cycle that incorporated 4 phases of open approach. The target groups were a lesson study team in a project school. Data were collected from 3 steps of lesson study and analysis procedures were based on analyzing videos, protocols, and descriptive analysis. The research found that the teachers obtained development as follows: 1) during the step of collaboratively design research lesson, they discussed and shared knowledge in the mathematical textbooks of project, discussion in objective of the lesson and construction of open-ended problem situation, anticipation for students' thinking, and specification of issues for discussion in classroom; 2) in the step of teaching and collaboratively observing the research lesson, they obtained knowledge for teaching by presenting the open-ended problem situation, the occurred difficulty of students' problem solving, the students' thinking approach in problem solving, the association of approach in each learning unit, the sequencing of thinking, and the extension of students' incomplete thinking approach; and 3) during the step of collaboratively reflection on teaching practice, teachers obtained knowledge by reflecting the students' goal accomplishment, the students' learning process, the students' thinking approach, the efficiency of media, and the experts' recommendations. 


\title{
Keywords
}

\author{
Mathematical Knowledge for Teaching, Innovation of Lesson Study, Open Approach, Lesson Study \\ Team
}

\section{Introduction}

The findings of evaluation by The Trends International Mathematics and Science Study ( TIMSS, 2011), found that the Thai students' mathematical content and learning behavior, obtained average score in lower level than the international average score. Since its rank was the 34th out of 52 countries being evaluated. There were $23 \%$ of students who had competency in lower level than 1 . In addition, there was only $1 \%$ of them who had competency in level 4 (The Institute for the promotion of Teaching Science and Technology, 2013).

Furthermore, the evaluative findings of Programme for International Student Assessment (PISA, 2012), was in the rank of 50th out of 65 countries being evaluated. The average score was 427 points which was lower than the average value of OECD almost one level. There were $50 \%$ of students obtaining score in lower level than 2. Moreover, there were only $0.5 \%$ of students obtaining the highest average score (The Institute for the Promotion of Teaching Science and Technology, 2013). According to the report of conclusions in implementation of Educational Reform (1999-2008), it found that the mathematics learning achievements of Grade 6th and Grade 9th Students, were decreased continuously (Office of the Education Council, 2009). According to TIMSS 2011, it found that there were $86 \%$ of Grade 4 students being taught by Bachelor's Degree Teachers which were higher than the international average value as $57 \%$. But, there were only $50 \%$ of students being taught by teachers with readiness in teaching preparation. In addition, $47 \%$ of them were taught by the teachers with teaching confidence which was lower than the national average value (The Institute for the Promotion of Teaching Science and Technology, 2013). Thailand still lacked of mathematics teachers in both of the quantity and quality (Office of the Education Council, 2009). The teacher taught by telling, lecturing, and explaining new content, giving the example and assigning the students to do exercise following the example (Kammanee, 2005 cited in Changsri, 2012). It showed that although most of primary school teachers had high educational degree, they lacked of readiness and confidence in mathematical knowledge for teaching. Most of teachers' development was implemented in short course training in content. But, this technique caused the teachers to fail in teaching (Rowland \& Ruthven, 2011), owing to the lack of major factors in professional expertise caused by their own teaching experience (Loipha \& Inprasitha, 2004).

The teachers were able to change as well as create their new knowledge regularly through the interaction with mathematical content and students' learning process in classroom (Fennema \& Franke, 1992). For teachers' knowledge development, the school should be used as a unit for developing the major development so that the teachers could have self-development from the practiced work through their professional learning community (The Thailand Development Research Institute, 2013; Inprasitha, 2009), the congruent approach with mathematical teaching professional development by using the lesson study in Japan (Shimizu, 2006), on the basis of co-workers' cooperation (Fernandez \& Yoshida, 2004; Lewis \& Hurd, 2011; Stigler \& Hiebert, 1999), for setting the learning objective as well as students' long range of development (Lewis, 2002). The lesson study process led to the learning community which would help to improve the teaching from the changes of teachers' knowledge, belief, professional community, and teaching resources (Lewis et al., 2006; Lewis, 2009). The teachers developed more intensive content knowledge, and integrated the content knowledge and teaching with full potentiality from discussion (Lewis, 2002). They shared knowledge through the lesson study (Hiebert \& Stigler, 2002). The lesson study provided opportunity for teachers to improve their mathematical knowledge for teaching (Meyer \& Wilkerson, 2011; Corcoran \& Pepperell, 2011).

Since 2004, lesson study was adapted to be adequate with mathematical context classroom by Center for Research in Mathematics Education, Faculty of Education, Khon Kaen University (Inprasitha, 2011). In 2009, the project of mathematical teaching professional development by using the innovation of lesson study through the incorporation opened an approach into lesson study cycle in order to use it as the weekly working cycle of lesson study team (Inprasitha, 2011). After teachers' participation in the project, there was the learning community on the practice-based community, the teachers' mathematical knowledge for teaching was changed and the stu- 
dents' learning process was occurred (Inprasitha, 2012). The researchers wanted to know how the lesson study and open approach could enhance the teachers to develop their mathematical knowledge for teaching.

\section{Conceptual Framework}

\subsection{Mathematical Knowledge for Teaching}

The teachers' mathematics knowledge for teaching was not only the mathematical knowledge (Even \& Tirosh, 2002). It was the knowledge connecting between the content knowledge and pedagogical knowledge called pedagogical content knowledge (Shulman, 1986). It consisted of the knowledge of mathematical content, and integration of mathematical content with the students' learning process and teaching (Ball et al., 2008). The teachers had to obtain the knowledge of mathematics, pedagogical knowledge, and knowledge of learners' cognitions in mathematics. The teacher's beliefs determined one's behavior in classroom (Fennema \& Frank, 1992), their students' mathematical learning regarding to the conceptual knowledge, procedural knowledge, and connection the concept and strategy (Loipha, 2002).

The conceptual framework of mathematical knowledge for teaching was not precise in the teaching strategy, since the teaching was based on cultural context of classroom (Stigler \& Hiebert, 1999). Therefore, the researcher synthesized the conceptual framework of teachers' mathematical knowledge for teaching under the context of incorporation open approach into lesson study cycle and including 2 major factors as shown in Figure 1, which includes:

- School mathematics knowledge referred to the teachers' knowledge of mathematical content in school including the conceptual knowledge, and procedural knowledge.

- Pedagogical school mathematics knowledge referred to the teaches' knowledge in providing the students' learning experience by using the open approach including the school mathematics and the learner's cognition knowledge, and school mathematics and teaching knowledge.

\subsection{Innovation of Lesson Study}

The lesson study is the innovation of professional development in Thailand, its meaning of cycle in the teachers' weekly collaborative working as lesson study team including 3 steps (Inprasitha, 2011) as shown in Figure 1, which includes:

Step 1 collaboratively design research Lesson, in this step, the lesson study team used mathematics textbooks in the project, discussed the objective of learning unit as well as the lesson, analyzed the content of learning process and teaching, conjectured the students' difficulty, analyzed the connection of mathematical ideas and conjectured the students' ideas, and designed the open-ended problem situation and media.

Step 2 teaching and collaboratively observing the research lesson, in this step, a teacher in lesson study team taught by using the open approach based on research lesson. The other two teachers observed the classroom. The lesson study team had to collect the data which occurred in classroom according to discussion as well as agreement during the step of research lesson establishment.

Step 3 collaboratively reflection on teaching practice, in this step, the Lesson study team would discuss the collected evidences based on the different conjectured issues from the step of research lesson establishment, and occurred phenomena by emphasizing on reflection of propriety in the open-ended problem situation and media, and the students' problematic situation and ideas.

\subsection{Open Approach}

Open approach was a teaching strategy being incorporated into the lesson study cycle so that the students would study by themselves through problem solving process including 4 phases of teaching (Inprasitha, 2011) as shown in Figure 1, which includes:

Phase 1 posing open-ended problem, the teacher assigned task or made the students to face difficulty in problematic situation so that the problem situation posed by the teacher, would be the students' problem.

Phase 2 students' self-learning, individual/group of students used the ideas or strategy they had learned before as an instrument in solving the problem situation. The students made their planning as well as solved the problem. In this phase, the teacher and observer had to collect the students' ideas in details. The teacher ranked the order of teaching based on the students' ideas, and the students' ideas being posed in next phase. 


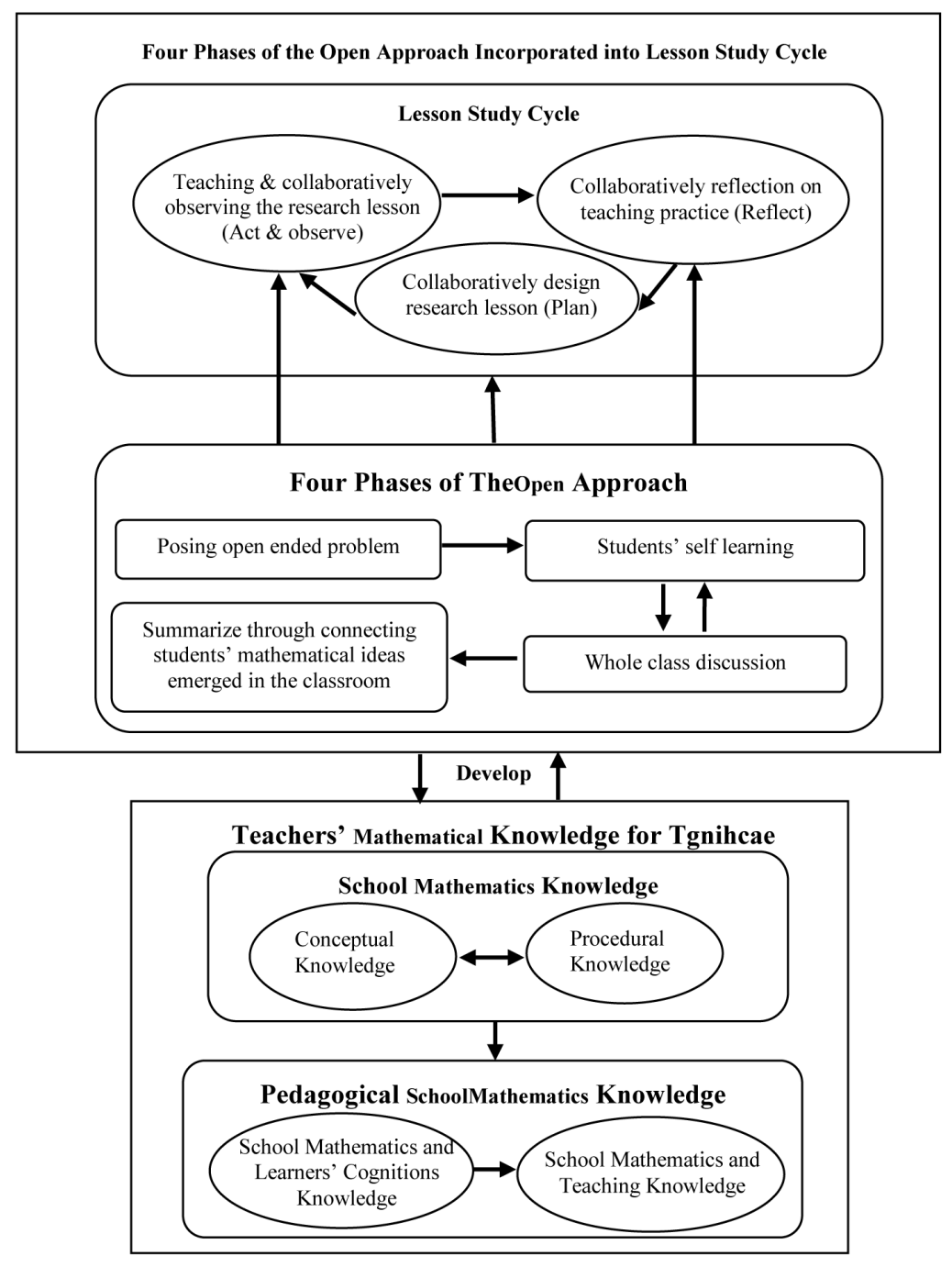

Figure 1. Conceptual framework.

Phase 3 whole class discussion, the individual/group of students presented one's ideas. The teacher had to observe classroom, collect the students' ideas and the connection of ideas in sequence. The comparison in ideas were discussed.

Phase 4 summarization through connecting students' Mathematical Ideas emerged in classroom, in this phase, the teacher had to rank the order of Mathematical Ideas posed by each/group of students, for connecting different ideas into conclusions, and extended into the construction of new problems by students themselves.

\section{Methodology}

This research is a case study that under context of the project of professional development for mathematics teacher by using the innovation of lesson study and open approach, during 2009-2011 academic years.

\subsection{The Target Group}

The target group was a lesson study team of Grade 1st students of the project school in Khon Kaen primary educational service area. The lesson study teams were selected by purposive sampling as follows: the school administrators as well as supervisors of educational service area supported this project very well. The teachers as lesson study team worked following the lesson study process strictly, and collaborated in working with the researchers continuously. 


\subsection{Entering into Research Area}

The researchers participated in working of lesson study team as the working group in the project, and school coordinator working based on lesson study cycle, with the teachers, school administrator, and supervisor.

\subsection{Data Collection}

Data were collected from 3 steps of lesson study cycle as follows:

- The participant observation, the researchers collaborated with the lesson study team in 3 steps, and collected data during the collaboration in designing the research lesson: collaborated in establishing the open-ended problem situation, conjecturing the students' ideas, discussing the objective of lesson. For the step of teaching and collaboratively observing the research lesson, the researchers collaborated in observing the classroom, recording the students' ideas, the whole class discussion, connection for concluding the mathematical ideas. For the step of collaboratively reflection classroom practice, the researchers collaborated in reflecting the students' ideas as well as association of ideas, and propriety of open-ended problem situation and the media.

- The interview, the researchers interviewed the lesson study team, experts, school administrator, and supervisor.

- The field note, the researchers collected the lesson study team field note from 3 steps.

- The video-tape recording, the researchers recorded video-tape of working of lesson study team during 3 steps.

\subsection{Data Analysis}

The researchers used data obtaining from participant observation, interviewing, field note taking, and videotape recording, for validation. Then, the researchers analyzed total data by using the descriptive analysis based on research conceptual framework.

\section{The Findings}

The development of teachers' mathematical knowledge for teaching in each steps of the lesson study cycle incorporated the open approach as follows:

\subsection{The Step of Collaboratively Design Research Lesson}

The lesson study team collaborated in research lesson regularly every week, based on 4 phases of framework of open approach as the teaching method of problem solving as shown in Figure 2. Consequently, the lesson study team had knowledge and understanding owing to:

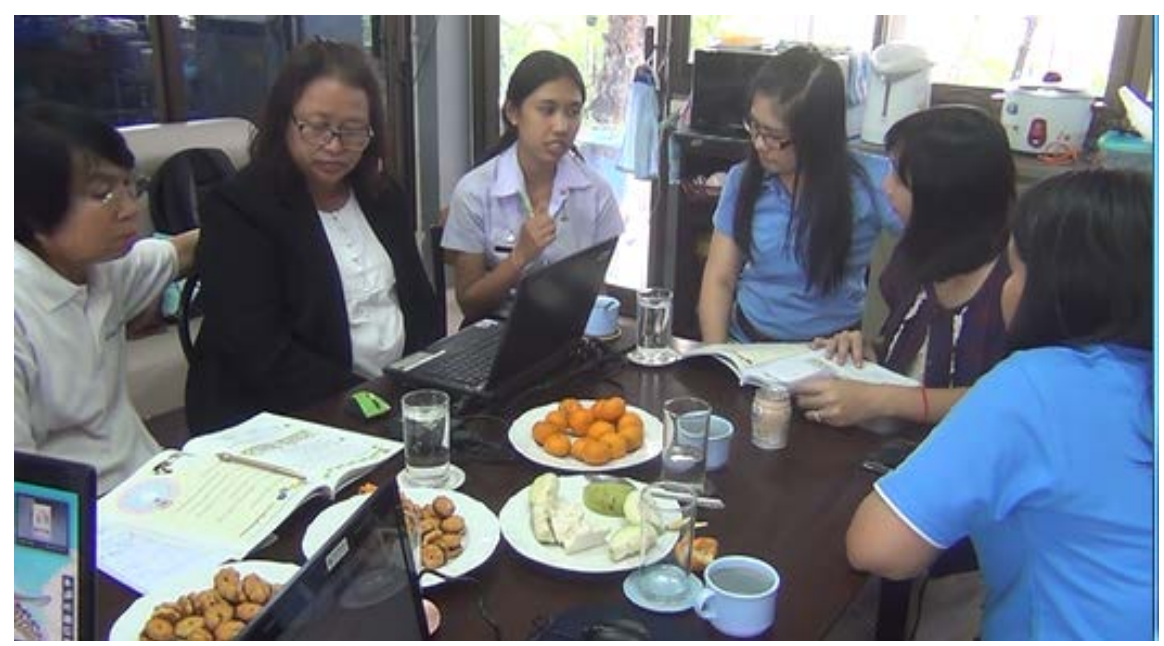

Figure 2. Collaboratively design research lesson. 
- The lesson study team discussed for analyzing the conceptual knowledge in the project textbook.

"For subtraction, we have to emphasize on the case of subtraction which case it would be, to find the left number, to find the difference."

(Teacher 1)

"For addition, the teacher would obtain 2 types of knowledge in Addition: 1) the addition as to increase, the former one is existed, and the another one is added, and 2) there are 2 things, supposing that there are some apples in this basket and that basket, when they are added together, how many it might be?"

(Teacher 2)

- The lesson study team discussed the procedural knowledge, through the objective of learning unit and lesson. There were 2 types of subtraction: 1) to take away, and 2) to subtract the difference.

"Take a look at the major objective, and the meaning of Subtraction in the meaning of difference, the students would be able to use the sign to represent the reading by using the Subtraction symbol."

(Teacher 3)

- The lesson study team discussed the learners' cognition and teaching knowledge, for ranking the teaching sequence which was appropriated.

"All of them would be put here, put it here... then, the problem would be put later as well. It meant that we tell... the, put it here... tell it first... the second round is to put the picture... the, the problem would be put."

(Teacher 2)

- The lesson study team discussed the conceptual knowledge, procedural knowledge, learners’ cognition, and teaching knowledge. They designed the open-ended problem situation.

"If it is to take away, how would the students do? How would they take it away? We have to design which media the students would use? Which way it would be taken away? For the difference, how would the students do? The needed to draw the lines for matching, don't they? We have to know at this point so that we could construct the media for students."

(Teacher 1)

- The lesson study team discussed the learners' cognition and teaching knowledge through conjecturing the students' ideas, the sequencing of ideas for discussion and association to conclusions.

"The students would draw a block as well as connect, and match it in circling it as a pair. Then, the symbolic sentence would be written the student' ideas. We would prepare the pictures or which pattern it would be? To put on the board."

(Teacher 1)

- The lesson study team discussed the learners' cognition and teaching knowledge, through issue consisted of the students' ideas to be discussed, compared, and concluded for associating into conceptual and procedural knowledge.

"Waiting for how would be his explanation, why does it become Subtraction? Want to know that why it is the subtraction? Before this, to take away, was used."

(Teacher 3)

\subsection{The Step of Teaching and Collaboratively Observing the Research Lesson}

The development of mathematical knowledge for teaching in 4 phases of open approach, consisted of the followings:

- The posing of open-ended problem

The teacher posed the task, stimulated the students to face with problematic situation as shown in Figure 3. The lesson study team observed the class, students' response to problem situation. As a result, the observer teachers obtained both of learners' cognition and teaching knowledge.

- The students' self learning

The students solve their problem, the lesson study team collected the students' ideas and organized the sequence ideas in order to discussed in class as shown in Figure 4. As a result, they obtained the learners' cognition knowledge.

- The whole class discussion and comparison

The lesson study team checked the students' ideas being occurred during discussion as shown in Figure 5, with conjectured ideas in the research lesson. As a result, they obtained both of school mathematics and 


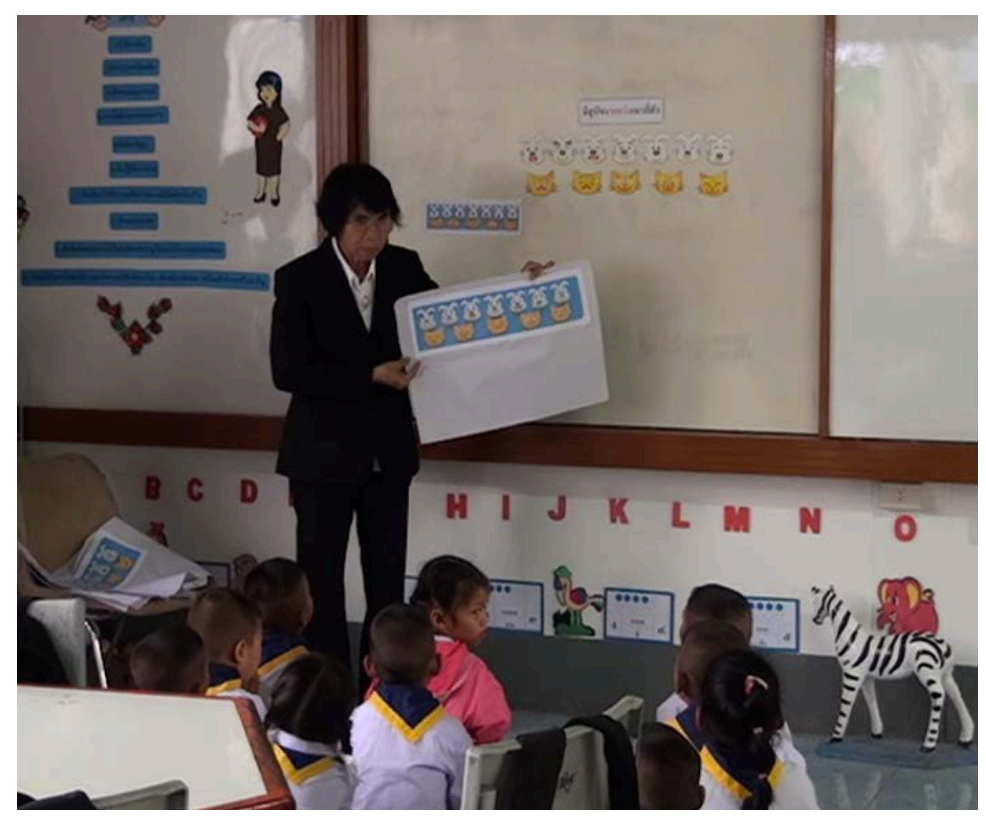

Figure 3. Teacher posed the problem.

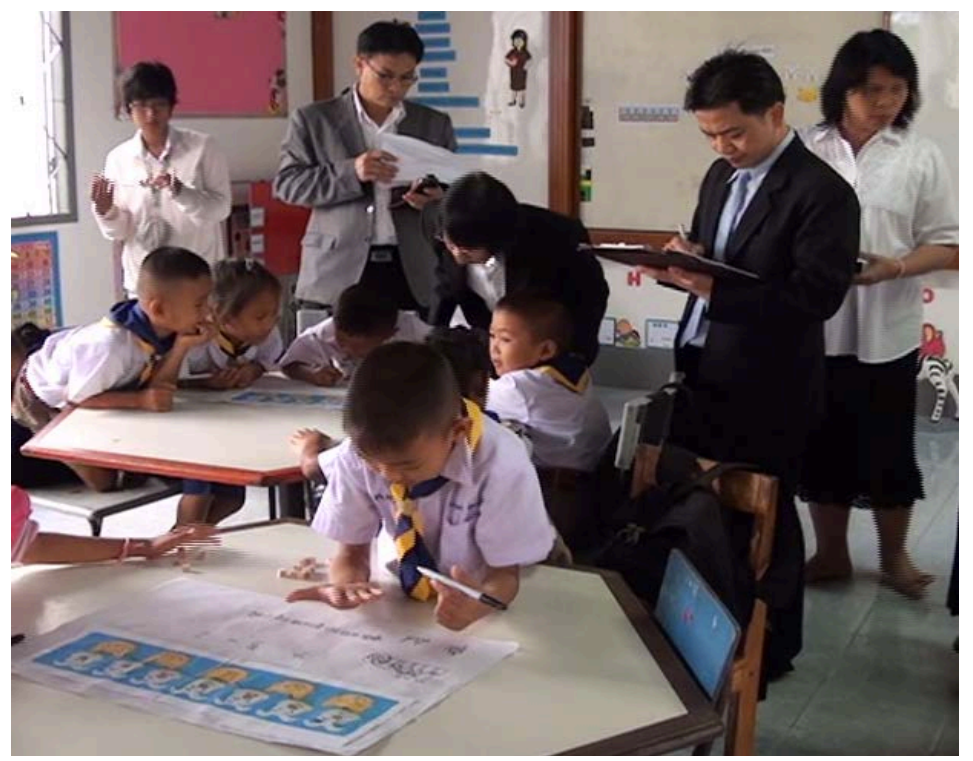

Figure 4. Observing of students' self learning.

pedagogical school mathematics knowledge.

- The summarizing through connecting the students' mathematical ideas emerged in classroom.

The teacher connected the students' ideas, extended the incomplete ideas into correct concept. As a result, the lesson study team obtained both of school mathematics and learners' cognition knowledge.

\subsection{The Step of Collaboratively Reflection on Teaching Practice}

Lesson study team reflected 4 issues from step 1 and step 2 of lesson study cycle including:

- The objective accomplishment of research lesson

"In part of objective accomplishment, the students are able to explain the meaning of Subtraction by comparing 2 things with different numbers." 


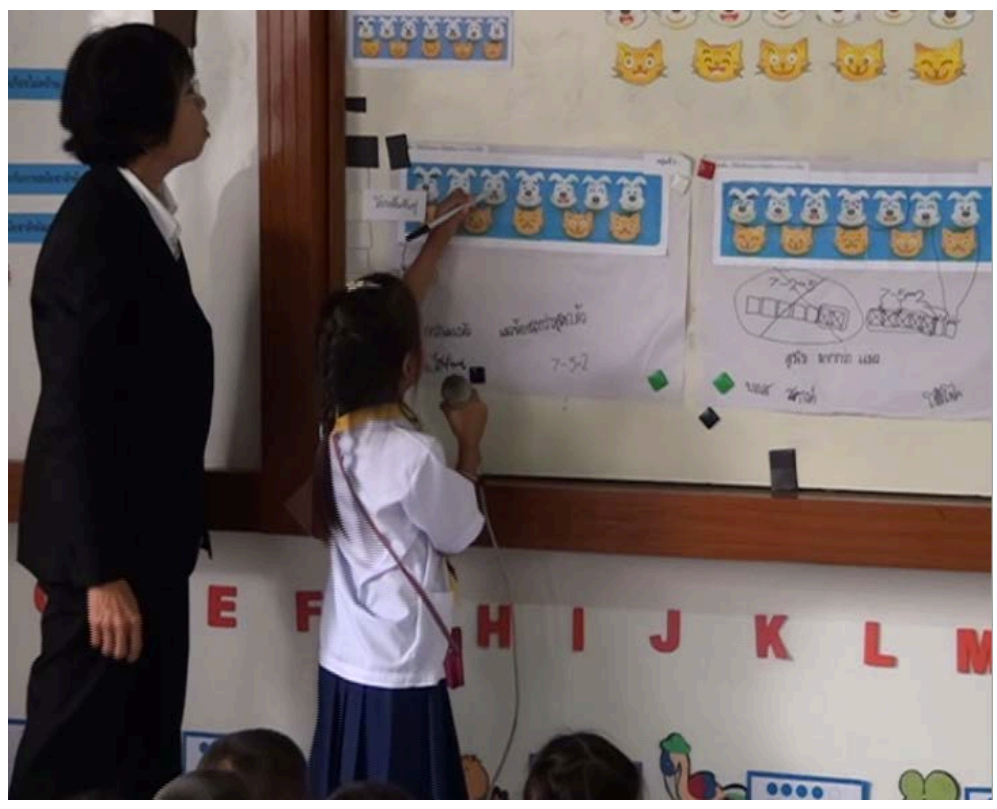

Figure 5. Student presented hers idea.

This teachers' cited suggests that teacher have conceptual knowledge of subtraction.

- The learning process

"He used strategy in drawing the lines. Then, the lines without being drawn would be called the left one. Writing the symbolic sentence, he would write $7-5=2$. The first 7 , referred to the dogs, 2 referred to this dog $=5$. The writing was continued. When the teacher knew that how he would do, in order to know that it is more than 2 . So, he changed into $7-5=2 . "$

(Observer Teacher 1)

This teachers' cited suggests that teacher have procedural knowledge of subtraction and learners' cognition knowledge.

- The students' problem solving ideas

"For the first time, there would be only one group to be thought to write $7-5=2$. The other groups would be written as $7-2=5$. But, while they were explaining during final duration, they would tell that 2. In fact, it would be the left one. They really understood." As shown in Figure 6.

(Observer Teacher 2)

This teachers' cited suggests that teacher have learners' cognition knowledge and teaching knowledge.

- The efficiency of problem situation and teaching media

"The situation, we want the students to pose problem or conjecture that are the cats equal to the dogs, or are they more than the others? This is the case because the emerged picture cause every student to think that they are equal."

(Specialist)

This specialist' cited suggests that teachers obtained procedural knowledge of subtraction and teaching knowledge.

\section{Conclusion and Discussions}

The lesson study was a major model for teaching professional development of Japan. It was recognized as a theory in mathematics education including the theories of problem solving approach as well as the theories of subject matter (Isoda \& Nakamura, 2010). In addition, it was the development cycle caused by creating a community of practice that based on teachers collaboratively work: design research lesson (plan), teaching and observing the research lesson (act \& observe), and reflection on teaching practice (reflect) (Inprasitha, 2011; Lewis, 2002). The lesson study cycle as an action research framework (Kemmis, 2014) includes: 1) plan, 2) act, 3) observe, and 4) reflect. Besides, the teaching professional development by using the Lesson Study was also 


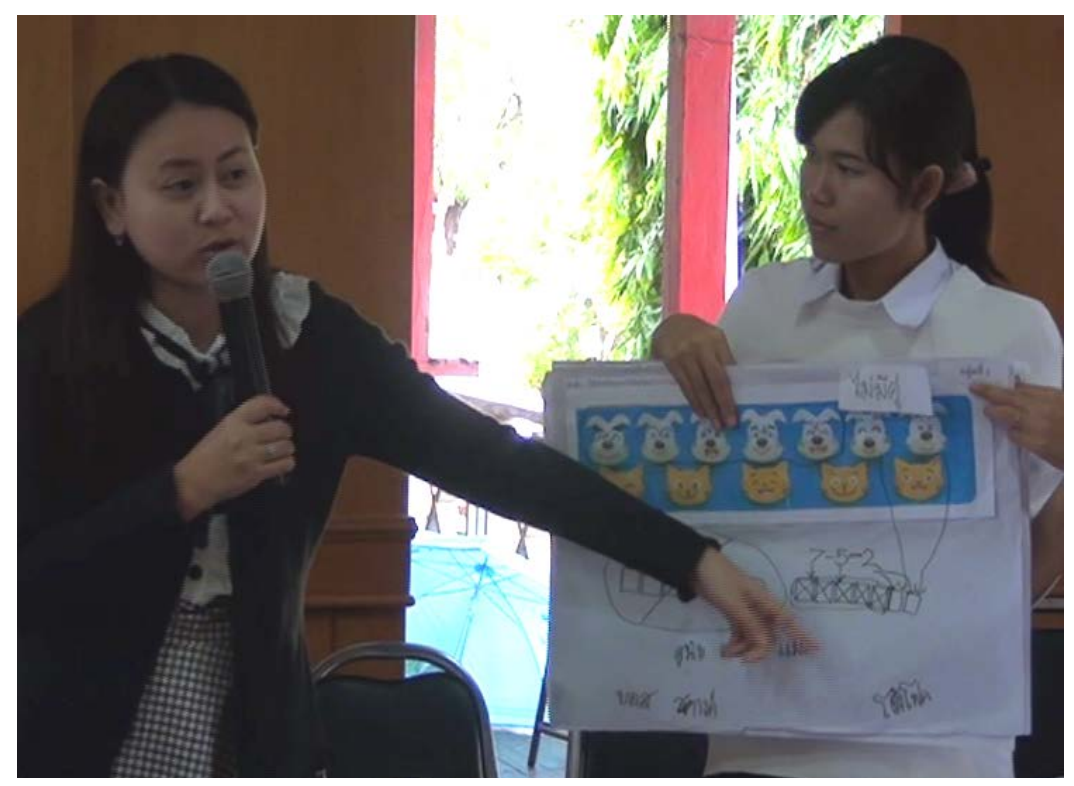

Figure 6. Reflecting students’ idea.

related to the different socio-cultural contexts (Stigler \& Heibert, 1999).

The findings of working according to the cycle incorporating open approach into lesson study, caused the teacher to change school mathematical knowledge including the conceptual knowledge and procedural knowledge, and integrated school mathematics knowledge into pedagogical school mathematics knowledge including students' cognition knowledge and teaching knowledge (Changsri, 2012). The lesson study caused the teachers to obtain intensive knowledge, and developed their teaching by looking at the students (Lewis, 2009). As a result, the teachers modified their teaching by working with their colleagues in checking and discussing their teaching (Baba, 2007). In addition, it was a process that the teachers inquired the approach of content as well as strategy to be taught in context of students' ideas (Takahashi et al., 2005), based on the ideas of knowledge on social context, and construction of knowledge through social interaction. Corcoran \& Pepperell (2011) found that by using the lesson study for developing primary school teachers' mathematical knowledge for teaching in Ireland, it made the foundation of mathematics teaching to be extended.

\section{Recommendations}

- The researchers should consider socio-cultural contexts of classroom carefully since it is the developmental process being dependent on social process. Therefore, the researchers have to act as a part of classroom being the teacher as well as researcher.

- The expert from institutions relating to the teaching professional development, could help the teachers to enhance their MKT.

\section{Acknowledgements}

This research was supported by the Higher Education Research Promotion and National Research University Project of Thailand Office of the Higher Education Commission, through the Cluster of Research to Enhance Quality of Basic Education. This research was partially supported by the Center for Research in Mathematics Education, Thailand.

\section{References}

Baba, T. (2007). How Is Lesson Study Implemented? Japanese Lesson Study in Mathematics: Its Impact, Diversity and Potential for Educational Improvement. Singapore City: World Scientific.

Ball, D. L., Thames, M. H., \& Phelps, G. (2008). Content Knowledge for Teaching: What Makes It Special? Journal of Teacher Education, 59, 389-407. http://dx.doi.org/10.1177/0022487108324554 
Changsri, N. (2012). Teacher's Perceived Beliefs about Teaching Practices in Teacher Professional Development Based on Lesson Study and Open Approach Context. Doctor of Philosophy Thesis in Mathematics Education, Graduate School, Khon Kaen: Khon Kaen University.

Corcoran, D., \& Peperell, S. (2011). Learning to Teach Mathematics Using Lesson Study. Mathematical Knowledge in Teaching. Springer: New York.

Even, R., \& Tirosh, D. (2002). Teacher Knowledge and Understanding of Students’ Mathematical Learning. Handbook of International Research in Mathematics Education. NJ: Lawrence Erlbaum Associates, Inc.

Fennema, E., \& Frank, M. L. (1992). Teachers' Knowledge and Its Impact. Handbook of Research on Mathematics Teaching and Learning. USA: National Council of Teacher of Mathematics.

Fernandez, C., \& Yoshida, M. (2004). Lesson Study: A Japanese Approach to Improving Mathematics Teaching and Learning. Mahwah: Lawrence Erlbaun Associates.

Inprasitha, M. (2011). One Feature of Adaptive Lesson Study in Thailand: Learning Unit. Journal of Science and Mathematics Education in Southeast Asia, 34, 47-66.

Inprasitha, M. (2012). Synthesis Report Format for Academically in School Management by Using Lesson Study and Open Approach. Khon Kaen: Clungnanavitaya LDT.

Inprasitha, N. (2009). Lesson Study: An Innovation for Teacher and Student Development. Doctor of Education Thesis in Curriculum and Instruction, Graduate School, Khon Kaen University.

Isoda, M., \& Nakamura, T. (2010). Mathematics Education Theories for Lesson Study: Problem Solving Approach and the Curriculum through Extension and Integration. Journal of Japan Society of Mathematical Education, 92, 5.

Kemmis, S., Mctaggart, R., \& Nixon, R. (2014). The Action Research Planner: Doing Critical Participatory Action Research. Singapore: Springer. http://dx.doi.org/10.1007/978-981-4560-67-2

Lewis, C. C. (2002). Lesson Study: A Handbook of Teacher-Led Instructional Change. Philadelphia, PA: Research for Better Schools, Inc.

Lewis, C. C., \& Hurd, J. (2011). Lesson Study Step by Step: How Teacher Learning Communities Improve Instruction. Portsmouth, NH: Heinemann.

Lewis, C. C., Perry, R. R., \& Hurd, J. (2009). Improving Mathematics Instruction through Lesson Study: A Theoretical Model and North America Case. Journal of Mathematics Teacher Education, 12, 285-304.

Lewis, C. C., Perry, R. R., \& Murata, A. (2006). How Should Research Contribute Instructional Improvement? The Case of Lesson Study. Educational Researcher, 35, 3-14. http://dx.doi.org/10.3102/0013189X035003003

Loipha, S. (2002). Research Report of Development Cooperation Activities for Teaching Mathematics, Grad 6. Khon Kaen: Khon Kaen University.

Loipha, S., \& Inprasitha, M. (2004). Teacher Professional Development to Promote Mathematics Learning. Khon Kaen, KKU Journal of Mathematics Education, 1.

Meyer, D. R., \& Wilkerson, L. T. (2011). Lesson Study: The Impact on Teachers’ Knowledge for Teaching Mathematics. In Lesson Study Research and Practice in Mathematics Education (pp. 15-26). New York: Springer. http://dx.doi.org/10.1007/978-90-481-9941-9 2

Office of the Education Council (2009). Proposals for Educational Reform in the Second Decade (2009-2018). Thailand: Office of Educational Policy and Planning.

Office of the Education Council (2009). Summary of Results for the Nine Years of Education Reform (1999-2008). Bangkok: V.T.C. Communication Ltd.

Rowland, T., \& Ruthven, K. (2011). Introduction: Mathematical Knowledge in Teaching. In Mathematical Knowledge in Teaching (pp. 1-5). New York: Springer. http://dx.doi.org/10.1007/978-90-481-9766-8_1

Shimizu, S. (2006). Professional Development through Lesson Study: A Japanese Case. The APEC International Symposium on Innovation and Good Practices for Teaching and Learning Mathematics through Lesson Study, Khon Kaen.

Shulman, L. S. (1986). Those Who Understand: Knowledge Growth in Teaching. Educational Researcher, 15, 4-14. http://dx.doi.org/10.3102/0013189X015002004

Stigler, J., \& Hiebert, J. (1999). The Teaching Gap. New York: The Fee Press, a Division of Simon and Schuster, Inc.

Takahashi, A., Watanabe, T., Yoshida, M., \& Wang-Iverson, P. (2005). Improving Content and Pedagogical Knowledge through Kyozaikenkyu. In Building Our Understanding of Lesson Study (pp. 101-110). Philadelphia, PA: Research for Better Schools, Inc.

The Institute for the Promotion of Teaching Science and Technology (2013). Conclusion TIMSS Project 2011. Grad 4. Bangkok: IPST.

The Institute for the Promotion of Teaching Science and Technology (2013). PISSA 2013 Executive Summary of Mathemat- 
ics, Reading and Science. Bangkok: IPST.

The Thailand Development Research Institute (2013). Proposal for Reform of Basic Education that Establish Accountability. Document for Seminar, Bangkok: TDRI. 
Scientific Research Publishing (SCIRP) is one of the largest Open Access journal publishers. It is currently publishing more than 200 open access, online, peer-reviewed journals covering a wide range of academic disciplines. SCIRP serves the worldwide academic communities and contributes to the progress and application of science with its publication.

Other selected journals from SCIRP are listed as below. Submit your manuscript to us via either submit@scirp.org or Online Submission Portal.
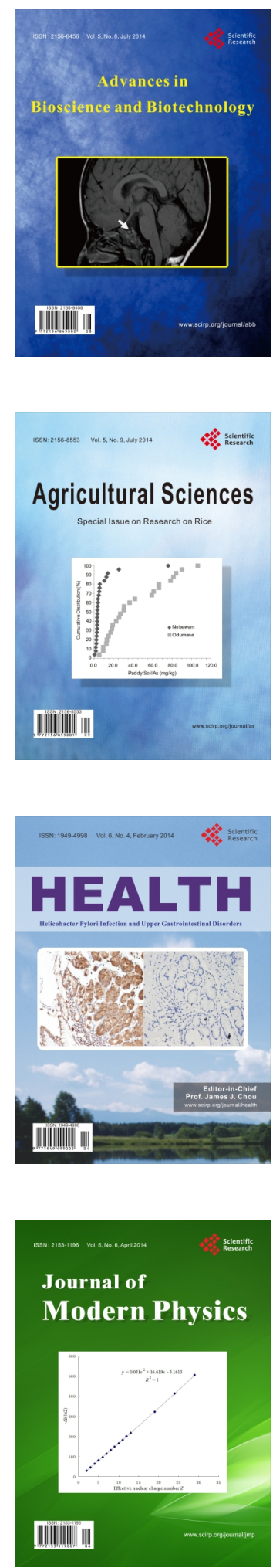
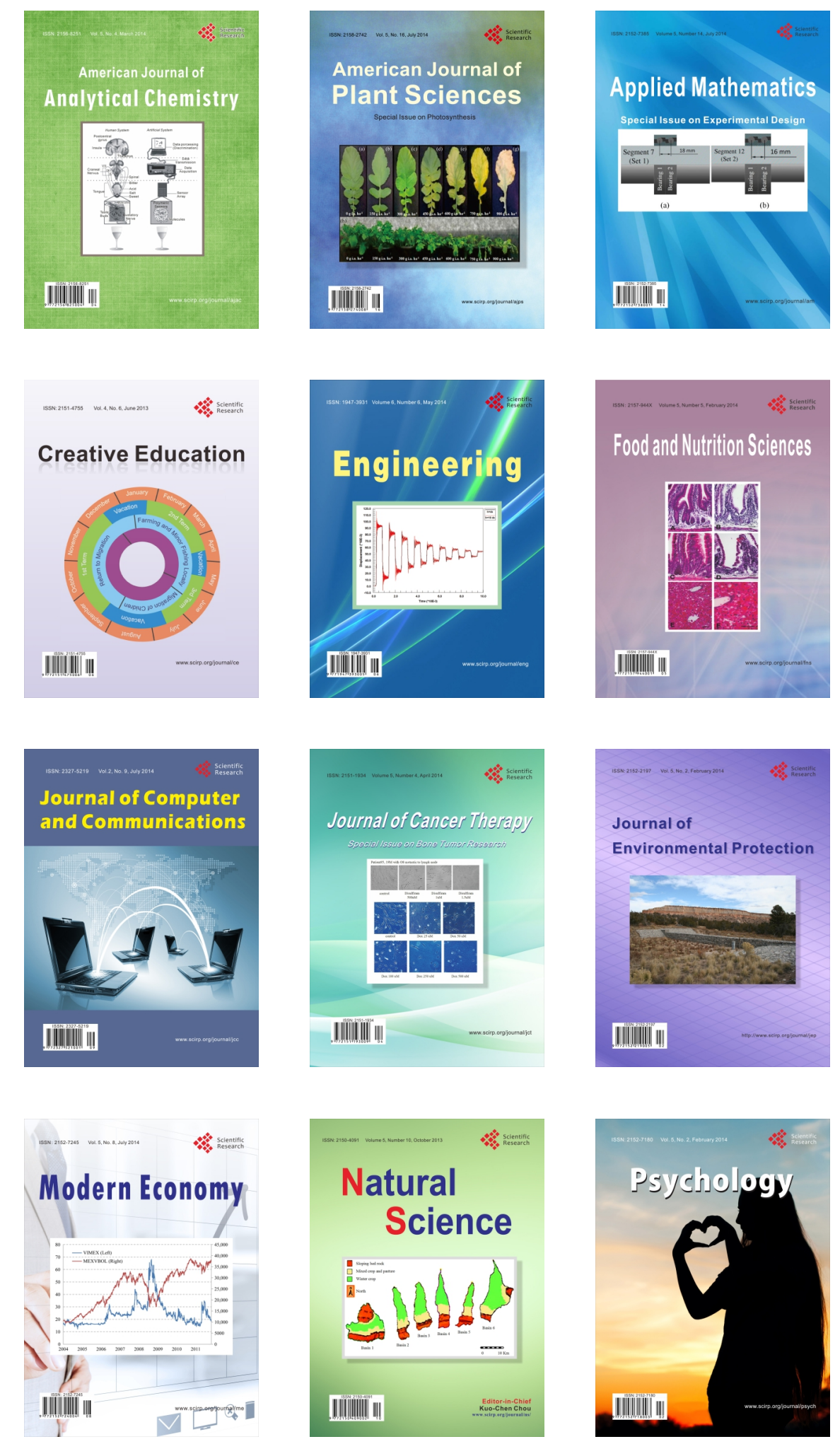